\title{
Research on Inheritance of Straw Tied Engraved Techniques in Western Region

\author{
Xu Li
}

Xi' an International University, Xi' an, Shaanxi, China, 710077

Keywords: Inheritance, Straw Tied Engraved Techniques, Western Region

\begin{abstract}
Straw tied engraved technique was known as "the model of Oriental Constitute Studies "since the moment is found by the Western academia with high academic value. In this paper, we take the straw tie engraved for the study, carried out a detailed summarize of bar engraved techniques for the first time. In theory would tie engraved techniques are outlined for further research on a range of issues straw tie engraved rescue protection and exploitation provided detailed technical data and theoretical support.
\end{abstract}

\section{Introduction}

Bar carved technique has a long history. When the Ming Dynasty Emperor Yongle Emperor Zhu Yuanzhang decided to have moved the capital from Nanjing to Beijing, he decided to build a watchtower in each of the four corners of the Forbidden City. Yongle Emperor had dictated, turret beam must be nine, eighteen pillars seventy-two ridges. In the history of the building, so the building has not seen anyone, not to mention personally built before. The nine beams eighteen column seventy-two ridge pavilion inspiration is produced in a thin forest stalks stick inserted multilayer roundworm cage. Inspired by the artisans of the cage, the Forbidden City turret figured out the way to make iron out the pulp-like type, and finally repair has become now still exist Palace turret.

\section{Research on Straw Tie Engraved Techniques}

"Bar" refers to a method and then with a fine awl garish bamboo stick connected on the one hand. On the other hand it refers to the process of structural connections with Mao Cheng

"Cutting" refers to portray the meaning, mainly refers to Mao birch Betula open trenching process. Sorghum straw to be able to combine precision and constitute various forms of ancient architecture, you must use a method similar to the structure of wooden Mao Cheng Song Dynasty wood to create law without adhesive. Its unique needs Hua Mao sculpted with a knife.

Carved bar "bar" mainly refers to a variety of configurations with the "six column lock" done; "moment" refers to the open birch and grooving braided straw when. Straw tie engraved techniques much, but require a higher fineness, through the work of research and numerous interviews with Mr. $\mathrm{Xu}$, summed up the straw tie engraved basic features:

1 , the structure features antique buildings;

2, balanced, stable physical characteristics;

3 , the geometric characteristics of camphor, groove, angle;

4, ornamental characteristics of ancient Chinese architecture;

5, creative characteristics of "six solid". Straw tie carved exquisite craftsmanship, not only high artistic ornamental value, scientific value, practical value is also high, involving geometry, structural mechanics, aesthetics, architecture and so on. Bar carved craft effective and unique use of sorghum straw that old texture, the ancient Chinese architectural grandeur and elegance to show its head, vivid, full Chinese folk arts and crafts profound. 


\section{The Main Value of Straw Tie Engraved Techniques}

The Academic Value. Straw tie by moment, can understand Chinese traditional architecture beams, columns, ridges, and many other ancient brackets constitute academic issues, such as:

The composition of ancient architecture includes the ancient beams and between; beams and columns; ridge beam and regulation. The reproduction process in the Ming Dynasty craftsmen invention Palace turret of the building, in particular for the study of ancient architectural structures architecture has opened up a new way and a new way of thinking.

The principle of respect rack includes a number of buildings with columns and vertical and horizontal beams Yang combined into various forms of beams, load building through the upper beams, columns passed to the foundation. Retaining walls only from the partition of the role does not carry the load. Stacked with vertical and horizontal flow outward from the stacked column lock pick suspended fighting chess, this is a transition member between the columns and beams, and gradually developed into a pillar between the upper and lower mesh net post or between the roof beams overall structural layer, which is an ancient form of Chinese ingenious wooden structure of another embodiment. 1/4 single building standardization. Chinese ancient palaces, temples, houses, etc., often made up of several individual buildings combine arranged groups. Whether single building size, the appearance of the contour by order group, housing body, the roof of three parts: The following is a bar and order from the moment it is the base model, supporting the whole house; stand on the stage group is house body, the skeleton column for the amount, during installation of doors and windows sliding door; the above is caused by roof truss roof made of soft, elegant curves, stretching out on all sides than the house itself, covered with tiles. Roof celebration, Volume Ceiling, hanging Peak, hard top, Spire, etc., eaves of the points, and then can be combined into more forms.

The Arts Value. Bred Chinese traditional folk culture in the artistic spirit qualities ethnic origin, cultural genes, which accumulated from the long-term practice of life, productive labor in the great spirit of the Chinese nation, is down from generation to generation and deposition of artistic ideas of the nation, the essence of thought It is the essence and core of folk art and culture. Therefore, in today's potential threat of global integration, how to ensure that national characteristic folk purely spiritual, national art is an important task for each nation can not be avoided. As one of the carrier means and human culture preservation and transmission, capable of accurately engraved bar, a good passing folk art, Chinese ancient architecture and other cultural information to everyone in the world, thus creating a unique culture and personality noble nation great national spirit. The value of this is immeasurable. Straw tie carved itself a unique in the world of crafts. Has a very high artistic value, its manufacture is difficult, making work a few months at least, as many as more than a year. Most of the products produced after, it was the major collection of art galleries and little work has also been simple personal collection. Coupled founder illness has been unable to personally created, leaving the more significant precious works. Straw tie engraved as traditional arts and crafts, rooted in folk, is a valuable cultural heritage, the national spirit of earth is DNA, which carries the traditional virtues of the people of earth, bearing the Chinese civilization, the Chinese nation is standing forever I'm in the world of art and culture in a position foundation. In 1991 and 2009, he has been to Japan and Spain, Hong Kong, participate in folk art exchanges, more works by collectors United States, Japan, Canada and other countries and Taiwan, Hong Kong collection. Straw tie has become a must to cut interest foreign tourism projects. Antique architectural model "Tiananmen" and other masterpiece into the ranks of the senior crafts, and country gift gift collection Nagano Prefecture, Japan; "Buddhist House" and "Palace turret" by the Chinese Art Museum collection; "Yellow Crane Tower" by the China Foreign Trade companies rushed to Toronto, Canada on display. The tie engraved art has won the China Federation of Literature, the Special Gold Award Chinese Folk Literature and Art Association, and the provincial government.

The Economic Value. From 1991 onwards, straw engraved on the bar attracted worldwide attention. The government straw tie engraved for a contact use next convenient land transportation, location advantages, the construction of a leisure, fitness, tours of ancient, agriculture, tourism and other farm tour project. Most tie engraved works have been collected, a complicated work of about 50,000 RMB. It is a simple work, such as arches also reached 3 thousand dollars. Therefore it has a 
high collection value and market prospects. Thus, the economic aspect of the project has a certain value for development.

\section{The Status of Bar Carved Straw of Western Region}

The activated protection, protection has become a whole lot of intangible cultural heritage protection of cultural heritage protection expert consensus. The so-called activated protection as I understand it, to folk arts and crafts, like children, like little time not only feeding, not starvation but also to raise, and raised so that the healthy growth to make it multiply sons. Protection of the space-time is not constant protection, not treat it as a heritage, antiques, but to make it live in people's lives. And compatible with the environment in different periods, it is necessary that we provide the necessary conditions and related policies.

Folk arts and crafts as often as the family's "trade secrets" are not easily successor, when the next generation said they did not like when the family inheritance chain can easily break; traditional apprenticeship environmental impact of modern society, "study with a teacher "' Art does not push the body, "the old saying is traditional and modern economic and social impact of foreign culture to pieces; not the apprentice could not find the master, but could not find the master apprentice;" Arts for art is not "growing phenomenon, which also contributed to the lack of high-end talent. Plaque lack of high-end talent, but also led to a massive waste of scarce raw materials. Traditional craftsmanship by "social" in heritage this way is getting narrower and narrower.

The intangible cultural heritage protection lags and intangible cultural heritage, natural heritage protection an important reason for unequal treatment of non-endangered heritage items. In recent years, natural heritage, intangible cultural heritage at the national and local governments to invest heavily, but also protection, is built. But for non-living folk heritage items not concerned but do not see its value. "Protected area" should exclude the most protected heritage.

We believe that the tie engraved heritage is the most effective way: social heritage. As the main carrier of social inheritance, as personnel training center for arts and crafts schools, arts and crafts for the development of the country had made tremendous contributions. Commentary before and after the grant of more than 300 state-level arts and crafts masters, 70\%, or from the Arts and Crafts College graduation, or college training in these too. With the national institutions merge or according to the market demand for professional adjustment, teaching arts and crafts locate most universities no longer focus on teaching traditional arts and crafts to teach. To this end, universities should be restored or add new educational content, it used to overcome the traditional arts and art institutions and heritage awareness opposition.

\section{Inheritance of Straw Tie Engraved Technology of Western Region}

Through the efforts of the whole society, and gradually establish a relatively complete, with Chinese characteristics, the intangible cultural heritage protection system, so that our precious, endangered and historical, cultural and scientific value of the effective protection of intangible cultural heritage, and to pass along and carry forward.

Protection and rescue first, rational use, inheritance and development. Correctly handle the relationship between protection and utilization, insist on the protection of intangible cultural heritage of authenticity and integrity, to prevent misunderstanding of the intangible cultural heritage, distorted or misused. On the basis of scientific identified, take effective measures to make the intangible cultural heritage in the whole society be recognized, respected and encouraged.

Full bar carved works, use tie township engraved actively open bar carved pavilion, closely integrated with the local farm tours, prompting more people to care about rolling moment, to participate in the related industrial chain engraved tie them, so as to the moment the loudest tie card flourish.

Closed to break the traditional thinking, extensively absorb interested in the art of tie engraved teenagers, cultivate a skilled young team. Training young people's interest in the art-loving nation, the formation of local folk art and culture of strong emotions and aesthetics, as well as to explore 
the artistic value of its due.

Folk Arts Resources has a strong regional, it comes from the private sector, growing on a particular land, our heritage to ensure its strong regional characteristics, in determining the object because based on local culture, in line with local economic development to be scientific and rational development, utilization and protection. In the development, utilization and protection ideology to change, to pay full attention to the development of mining resources in public service, the arts and crafts of local economic development into the education system, and truly reflect regional arts and crafts education, nationality, promote the development of the western arts and crafts, utilization and protection for both the local economic construction.

With the accelerating trend of globalization and strengthening the process of modernization, some of the acts rely on dictation and cultural heritage is disappearing; many endangered traditional skills; there are a large number of historical and cultural value of precious objects and materials have been lost or destroy outside; arbitrary abuse have occurred, the phenomenon of over-exploitation of intangible cultural heritage when. Strengthen our intangible cultural heritage protection is urgent.

\section{Conclusion}

Whether straw engraved tie can get fully inheritance and development, a complete system of legal protection of intangible cultural heritage is a key. Reasonable solution to tie engraved inheritance relationship between people and schools; industrial development after the distribution of profits; tie engraved Inheritance Relationship between the local government and other non-material cultural heritage protection legal regime is extremely important.

\section{Acknowledgements}

Fund Project: Research on National Social Science Foundation Art Project, Innovation and Development of Shaanxi Folk Straw Weaving Art. (sy2016014)

\section{References}

[1] Li Jingyuan. History of Chinese Ancient Architecture, Vol. 6 (2014) No 53, p.25-26

[2] Wang Qunyong. The Principle of Building Structures, Vol. 12 (2015) No 27, p.74-76

[3] Hou XuSi. Construction Mechanics, Vol. 30 (2014) No 19, p.144-145

[4] Wang Kuailiang. Model Design Practice, Vol. 29 (2011) No 27, p.21-23

[5] Sun Jing. History of Chinese Ancient Architecture, Vol. 8 (2013) No 27, p.57-60 